\title{
AMENDMENTS
}

\section{Author Correction: Glacial deep ocean deoxygenation driven by biologically mediated air-sea disequilibrium}

Ellen Cliff, Samar Khatiwala (D) and Andreas Schmittner (D)

Correction to: Nature Geoscience https://doi.org/10.1038/s41561-020-00667-z, published online 4 January 2021.

In the version of this Article originally published, in the first sentence of the Acknowledgements the grant number 'OCE-1924315' was incorrect; it should have been 'OCE-1924215'. It has now been corrected in the online versions of the Article.

Published online: 11 January 2021

https://doi.org/10.1038/s41561-021-00689-1

( ) The Author(s), under exclusive licence to Springer Nature Limited 2021

\section{Publisher Correction: Glacial deep ocean deoxygenation driven by biologically mediated} air-sea disequilibrium

Ellen Cliff, Samar Khatiwala (D) and Andreas Schmittner (D)

Correction to: Nature Geoscience https://doi.org/10.1038/s41561-020-00667-z, published online 4 January 2021.

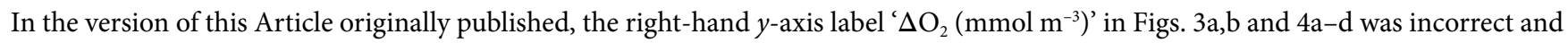
should have read 'Concentration $\left(\mathrm{mmol} \mathrm{m}^{-3}\right)$ '. The label for the colour scale bar for Fig. $3 \mathrm{c}, \mathrm{d}^{\text {' }} \mathrm{O}_{2}$ saturation (\%)' was also incorrect and should have read ' $\Delta \mathrm{O}_{2}\left(\mathrm{mmol} \mathrm{m}^{-3}\right)$ '. The online versions of the Article have been corrected.

Published online: 1 March 2021

https://oi.org/10.1038/s41561-021-00710-7

(c) The Author(s), under exclusive licence to Springer Nature Limited 2021 